\title{
Properties of Concrete with Waste Glass Powder (Gp) as Fine Aggregate Replacement
}

\author{
J.Premalatha, R.Srinivasan
}

\begin{abstract}
In the present research, the feasibility of using waste glass as replacement for natural river sand was investigated. Glass wastes dumped in landfill pose environmental pollution and research on its reuse in construction industries need to be carried out . An experimental work was performed to study the slump, unit weight, compressive strength, splitting tensile strength, flexural strength, modulus of elasticity, ultrasonic pulse velocity, dry density and chloride ion penetration test at different curing ages at 7, 14 and 28 days of concrete. Investigation on concrete properties with various $\%$ of glass powder $(0 \%, 5 \%, 10 \%, 15 \%$ and $20 \%$ ) were done on fresh and hardened concrete. The complete stress-strain behaviour, mechanical strength and durability properties of concrete with partial replacement of natural river sand by glass powder were investigated through standard tests.The optimum glass powder content is found out by testing the specimens prepared using different grades of concrete (M20, M30, M40,M50 and M60). All the fresh concrete mixes were tested also for the workability properties by conducting slump cone tests. According to the test results, it is observed that the slump value of fresh concrete increase gradually with \% of glass powder upto $40 \%$ replacements. The gradual increase in compressive strength, flexural strength and split tensile strength with the addition of waste glass powder upto $30 \%$ was observed. The addition of $40 \%$ and $50 \%$ replacements, the strength values of concrete are comparable with that of the control mix. The density and modulus of elasticity of concrete also gradually increases from $0 \%$ to $50 \%$ addition of glass powder in the concrete.

The Rapid Chloride Penetration Test (RCPT) test results show that the chloride penetration rate is considerably reduced with addition of glass powder and permeability properties of concrete is enhanced upto $50 \%$ replacement levels. In order to prepare the concrete with compressive strengthThe optimum glass powder content is found to be $50 \%$ can be used as the replacement material for fine aggregates without much compromise on the strength and durability properties and to achieve economic and environmental benefits.
\end{abstract}

\section{INTRODUCTION}

Solid waste management is a very crucial issue for the society worldwide. Glass wastes form a major component of solid waste and being an inert and nonorganic material, it is non-biodegradable and its disposal into landfills create serious environmental problems. Using waste glass in concrete as fine aggregate provide better solution for its disposal problem and also prevent depletion of natural resources like river sand.

Since a very large space and lands are used to stockpile waste glass, it is very essential to find ways to reuse it or recycle it. The advantage of almost $100 \%$ recyclability of waste glass makes it as one of the material considered for the

Revised Version Manuscript Received on 10 September, 2019.

J.Premalatha, Professor, Department of Civil engineering, Kumaraguru College of Technology, Coimbatore, Tamilnadu, India.

R.Srinivasan, Assistant Professor, Department of Civil Engineering, Gnanamani College of Engineering, Namakkal, Tamilnadu, India. concept of waste to wealth, world wide.A variety of new products can be produced using waste glass. There are two main ways of use waste glass in concrete. Glass wool is one of the important form of glass which is used as an heat insulating material on roofs, walls and floors of buildings.Glass wool insulation is recyclable and reusable, so that it can be recycled for another applicationsafter its original use. Based on the citations, it is found that waste glass can be used in concrete in two ways, one is as fine aggregate as a replacement for natural sand and another one is as aSupplementary Cementing Material in concrete.Many research works have been done on concrete with glass waste as partial replacement for fine aggregate and coarse aggregates.

Waste management has become a critical challenge in developing countries like India. Unprecedented levels of waste material are produced due to rise in population and the management of solid wastes have arised as an alarming threat for healthy environment world wide.Since glass wastes are non-biodegradable material. Innovative methodologies of recycling need to be conventional to avoid their disposal in land fills.

\section{Objectives :}

The research objectives of the current work are :

- To design the mix proportions for five various grades (M20, M30, M40,M50 and M60) of concrete with different glass powder replacements $(0 \%, 10 \%, 20 \%, 30 \% 40 \%$ and $50 \%$ ) for natural sand in concrete.

- To investigate the workability properties of fresh concrete, mechanical properties of hardened concrete and their durability properties by testing the specimens prepared as per standard specifications.

- To investigate the detailed stress strain behaviour of concrete with different $\%$ of waste glass powder additions.

\section{MATERIALS AND METHODS}

\section{Materials}

\section{Cement}

Locally available ACC cement53 grade ( Ordinary Portland cement) confirming to (IS12269-1989), was used for the present research. The Standard consistency of cements was determined in accordance with (IS 4031 (Part 4)-1995). Pastes having standard consistency were used to determine the initial setting time and final setting time in accordance with IS 4031 (Part 5)-1995. The Physical and 
chemical properties of cement are given in Table1 and Table 2 .

Table 1 Physical properties of OPC53 grade cement

\begin{tabular}{|c|c|c|}
\hline Propenty & Vilue & Requiementis12269-19J9) \\
\hline Initial seting time & 70 minutes & Sinimum 30 minutes \\
\hline Final setting time & 360 minuter & Msximum 600 minutes \\
\hline Specific gavity & 3.15 & $15 \mathrm{H} 99.1959$ \\
\hline Normil cansistency & $305 \%$ & $=$ \\
\hline Fineness motanit & ESOS & $40 \%$ \\
\hline
\end{tabular}

Table2 Chemical composition of cement

\begin{tabular}{|l|l|}
\hline \multicolumn{1}{|c|}{ Chemical composition } & \multicolumn{2}{c|}{$\%$ content } \\
\hline Silica $\left(\mathrm{SiO}_{2}\right)$ & 21.00 \\
\hline Alumina $\left(\mathrm{Al}_{2} \mathrm{O}_{3}\right)$ & 5.20 \\
\hline Iron Oxide $\left(\mathrm{Fe}_{2} \mathrm{O}_{3}\right)$ & 2.20 \\
\hline Calcium Oxide $(\mathrm{CaO})$ & 67.39 \\
\hline Magnesium Oxide $(\mathrm{MgO})$ & 1.81 \\
\hline Sodium oxide $\left(\mathrm{Na}_{2} \mathrm{O}\right)$ & 2.10 \\
\hline Potassium oxide $\left(\mathrm{K}_{2} \mathrm{O}\right)$ & 0.20 \\
\hline Loss on ignition & 0.10 \\
\hline
\end{tabular}

\section{Sand}

Locally available natural river sand with maximum size of $4.75 \mathrm{~mm}$ and confirming to zone II as per IS 383-1987 was used as fine aggregates. The specific gravity of sand is 2.66 ,its water absorption is $3.0 \%$ and unit weight $1690 \mathrm{~kg} / \mathrm{m} 3$. A sieve analysis was carried out for the sand and presented in Table 3.3. and the grading curve for sand is given in Figure 1.

Table 3 Physical properties of sand

\begin{tabular}{|c|c|c|c|c|c|}
\hline $\begin{array}{c}\text { Sieve sivt } \\
\text { mats }\end{array}$ & $\begin{array}{l}\text { Weidht } \\
\text { reained } \\
\text { in } \mathrm{g}=\end{array}$ & Sictained & $\begin{array}{c}\text { Cumblatives } \\
\text { by weight } \\
\text { retained }\end{array}$ & $\begin{array}{l}\text { Cumulative } 5 \\
\text { by weight } \\
\text { passing }\end{array}$ & $\begin{array}{l}\text { prasitie } \\
\text { limit foo } \\
\text { gading zoue- } \\
\text { II }\end{array}$ \\
\hline 10 & i & 0 & 0 & 100 & - \\
\hline 475 & 90 & 9 & 9 & 91 & 90.100 \\
\hline 236 & 120 & 12 & 71 & 79 & $75-100$ \\
\hline$T 28$ & 170 & 17 & 38 & 62 & 55.98 \\
\hline 0.6 & 250 & 25 & 63 & 37 & $35-59$ \\
\hline 03 & 220 & 22 & 85 & 15 & 8.30 \\
\hline \multirow[t]{4}{*}{215} & 150 & 15 & 100 & e & $0-10$ \\
\hline & & Tonal $=$ & 316 & & \\
\hline & \multicolumn{2}{|c|}{ Fineness mosilin = } & 3.16 & & 3.37 .2 .1 \\
\hline & \multicolumn{2}{|c|}{ Sotcof envity = } & 2,56 & & \\
\hline
\end{tabular}

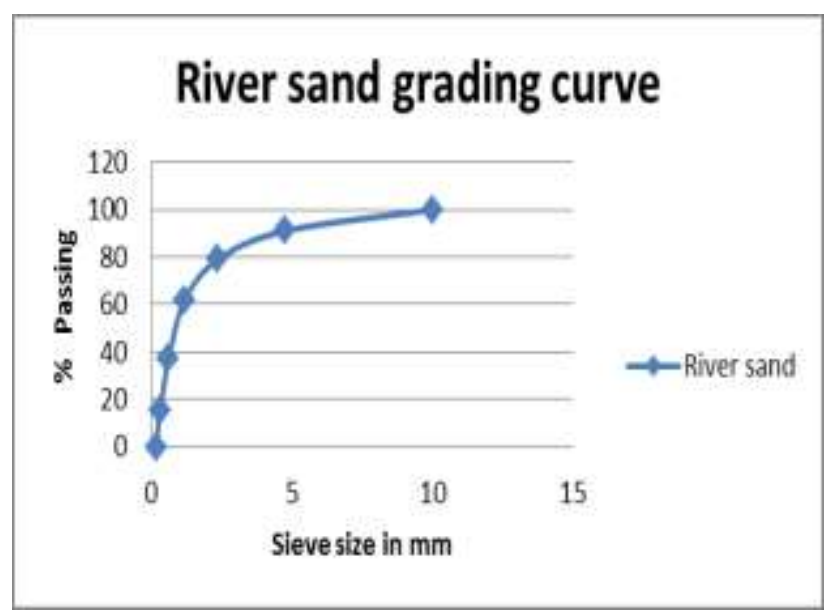

Figure 1 Grading curve of Natural sand

\section{Coarse Aggregate :}

Graded crushed granite coarse aggregates with maximum nominal size of $20 \mathrm{~mm}$ and down was confirming to IS:383(1987)was used as coarse aggregate in the concrete mixes.The specific gravity of coarse aggregate is 2.7 ,its fineness modulus is 6.7 , bulk density is $1800 \mathrm{~kg} / \mathrm{m} 3$ and its water absorption is $0.3 \%$. According to IS 383-1987, a sieve analysis was carried out coarse aggregates and presented in Table 4. and its gradation curve is given in Figure 2.
Table 4 Physical properties of Coarse Aggregates

\begin{tabular}{|c|c|c|}
\hline $\begin{array}{c}\text { Sieve size } \\
\text { mm }\end{array}$ & \% retained & \% passing \\
\hline 20 & 5 & 95.00 \\
\hline 12.5 & 15 & 85.00 \\
\hline 10 & 35 & 65.00 \\
\hline 4.75 & 86 & 14.00 \\
\hline 2.36 & 97 & 3.00 \\
\hline
\end{tabular}

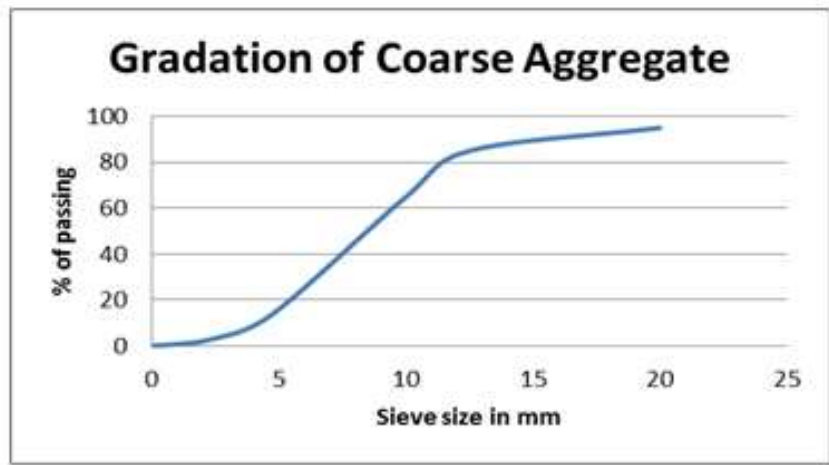

Figure 2 Gradation of Coarse Aggregates

Water:Ordinary Potable water is used for mixing and curing of test specimens.

Super plasticizer :

CONPLAST 430 received from Elkem India Pvt Ltd, Mumbai was used as the super-plasticizer in concrete mixes.

Waste Glass Powder:

Waste glass for this experiment was sourced from a glass recycling industry in the Coimbatore. This glass powder used in this research was prepared by crushing and milling process.The chemical composition and microstructure analysis of the glass powder was done using XRD analysis and SEM analysis and presented in Figure 2.3 and Figure 4. The typical chemical composition of the glass aggregate is given in Table 5 whilst particle size distribution is given in Table 6. The gradation curve for the glass powder used is given in Figure 2.5 and its sieving process is given in Figure 6.

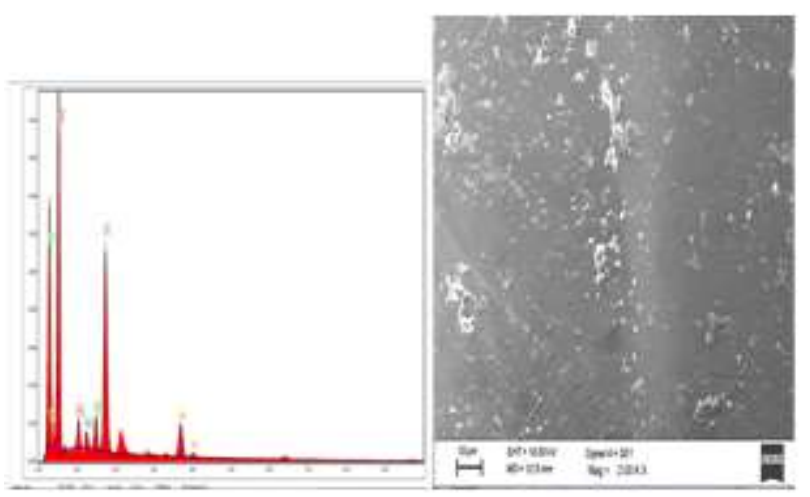

Figure 3 Chemical composition of glass powder Figure 4 Microstructure of Glass Powder by XRD Analysisby SEM Analysis

Published By:

Blue Eyes Intelligence Engineering \& Sciences Publication 
Table 5 Chemical composition of Glass powder ( \% by mass)

\begin{tabular}{|c|c|c|}
\hline Composition & $\begin{array}{l}\text { Glass powder } \\
56\end{array}$ & $\begin{array}{l}\text { River sand } \\
\text { की. }\end{array}$ \\
\hline S्ञाica( $\left(\mathrm{SiO}_{2}\right)$ & 71.30 & 8850 \\
\hline Alumina $\left(A, O_{3}\right)$ & 1.50 & 3.20 \\
\hline Gon Oxide $(\mathrm{Fe}, \mathrm{O})$ & 080 & 0.8 \\
\hline Calcium Oxide (ClO) & 920 & 7.10 \\
\hline Magnesium Orode( $\mathrm{M}$;O) & 250 & 0.18 \\
\hline Sodium oxde $\left(\mathrm{N}_{3} \mathrm{O}\right)$ & 1405 & - \\
\hline Potassium cxide $(\mathrm{K}, \mathrm{O})$ & 0.15 & 0.22 \\
\hline \begin{tabular}{|l|} 
Loss on ignition \\
\end{tabular} & 0.50 & 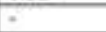 \\
\hline
\end{tabular}

Table6 Physical properties of Glass powder

\begin{tabular}{|c|c|c|c|c|c|}
\hline $\begin{array}{l}\operatorname{sint} \text { wit } \\
\operatorname{man}\end{array}$ & $\begin{array}{l}\text { Strrtalied } \\
\text { in pe }\end{array}$ & Sirtaista & $\begin{array}{c}\text { Cumulagive } \\
\text { by weight } \\
\text { retuined }\end{array}$ & $\begin{array}{c}\text { Cosmulatives } \\
\text { by weight } \\
\text { passing }\end{array}$ & 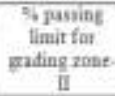 \\
\hline 10 & 0 & \% & 0 & 100 & \\
\hline+75 & 0 & 8 & a & 100 & \\
\hline 236 & 0 & 0 & 0 & 100 & \\
\hline 1.18 & 50 & 5 & 5 & 93 & $90-100$ \\
\hline 60 & 350 & प्रs & 40 & 60 & 80.100 \\
\hline 0,3 & 300 & 30 & 70 & 30 & $15-50$ \\
\hline 015 & 150 & 18 & 88 & t. & 0.15 \\
\hline \multirow[t]{3}{*}{8} & 120 & 12 & 100 & 6 & \\
\hline & & $\begin{array}{l}\text { Fineneis } \\
\text { modulus = }\end{array}$ & 3.16 & & $7.37-2.1$ \\
\hline & & Specfic envily & 2.49 & & \\
\hline
\end{tabular}

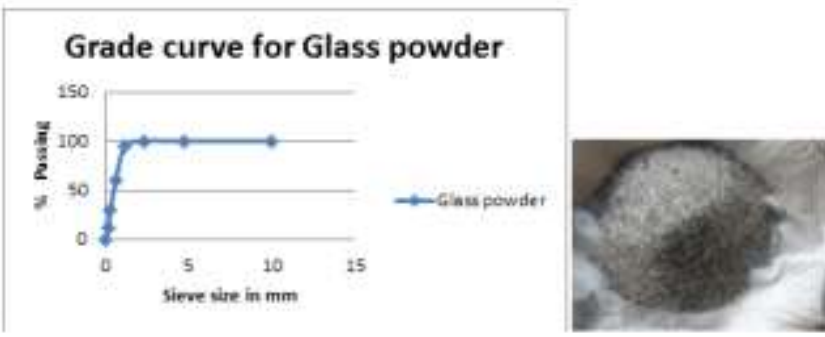

Figure 5 Gradation curve for Glass powderFigure 6 Glass powder sample

\section{METHODS}

Tests were conducted to find the workability properties, mechanical strength and the stress-strain behaviour of concrete with different glass powder replacement percentages of $0 \%, 0 \%, 20 \%, 30 \%, 40 \%$ and $50 \%$ are carried out. The concrete mix design for five different grades of concrete (M20, M30, M40, M50 and M60) were done in accordance with (IS: 10262 1982). The concrete mix proportions used for the test specimens are given in Table7.

Table 7 Mix proportions for concrete

\begin{tabular}{|c|c|c|c|c|c|c|}
\hline Grade & w/c & \begin{tabular}{|l} 
Cement \\
$\mathrm{kgm}^{3}$
\end{tabular} & $\begin{array}{l}\text { Sand } \\
\mathrm{kg}^{3} \mathrm{~m}^{3}\end{array}$ & $\begin{array}{l}\text { Coarse } \\
\text { aggregate } \\
\mathrm{kgm}^{3}\end{array}$ & $\begin{array}{l}\text { Water } \\
\text { content } \\
\text { litres } m^{3}\end{array}$ & \begin{tabular}{|l|} 
Super \\
plasticizer \\
$\mathrm{kg} \mathrm{m}^{3}$
\end{tabular} \\
\hline 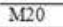 & 0.50 & 360 & 750.12 & 1142.10 & 180 & 0 \\
\hline $\mathrm{M} 30$ & 0.45 & 400 & 734.16 & 1117.8 & 180 & 0 \\
\hline M40 & 0.40 & 420 & 696.17 & 1256.2 & 140 & 4.2 \\
\hline M50 & 0.35 & 480 & 678.00 & 1223.4 & 140 & 4.2 \\
\hline M60 & 0.30 & 500 & 745.8 & 1135.6 & 140 & 8.4 \\
\hline
\end{tabular}

\section{MEASUREMENTS \& RESULTS}

\section{Workability of fresh concrete}

\section{Slump cone Test}

According to (IS: 1199 - 1959) workability test by slump cone on fresh concrete weretested and the results are plotted in Figure 2.7 The slump was in the range of $60-80 \mathrm{~mm}$ for M20 and M30 and its value increases to $80-100 \mathrm{~mm}$ for higher grades of concrete with super-plasticizer. The slump value of all the mixes increases with the addition of glass powder upto $30 \%$ and afterwards for $40 \%$ and $50 \%$ additions, the slump value got reduced. For concretes incorporating glass powder, no bleedingor segregation was detected.

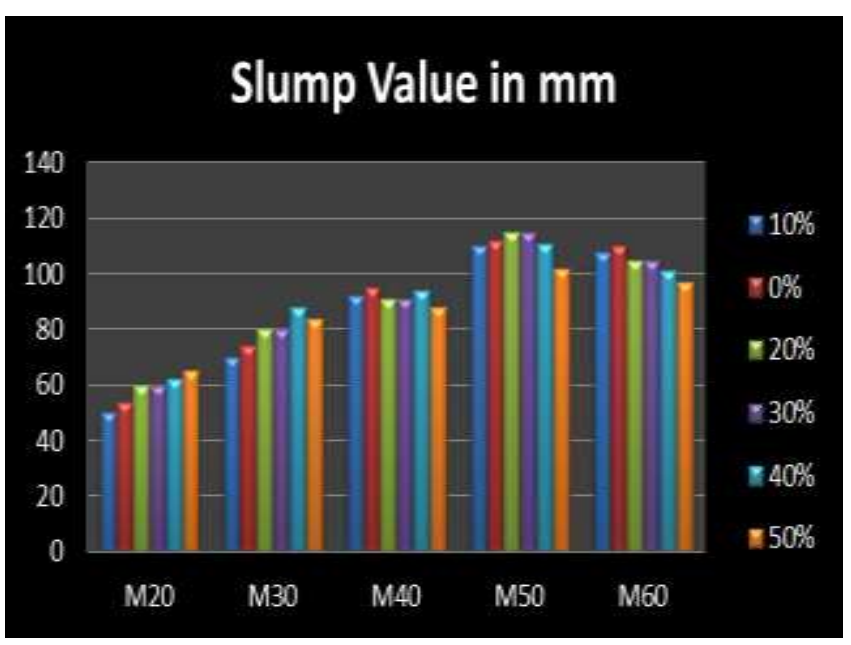

Figure 2.7 Compressive strength of M20 Concrete

\section{Bulk Density of concrete}

Very small variations in concrete density was observed with the addition of glass powder for all grades of concrete and shown in Figure 2.8. This may be due to very small difference between the specific gravity of glass powder and the natural sand.

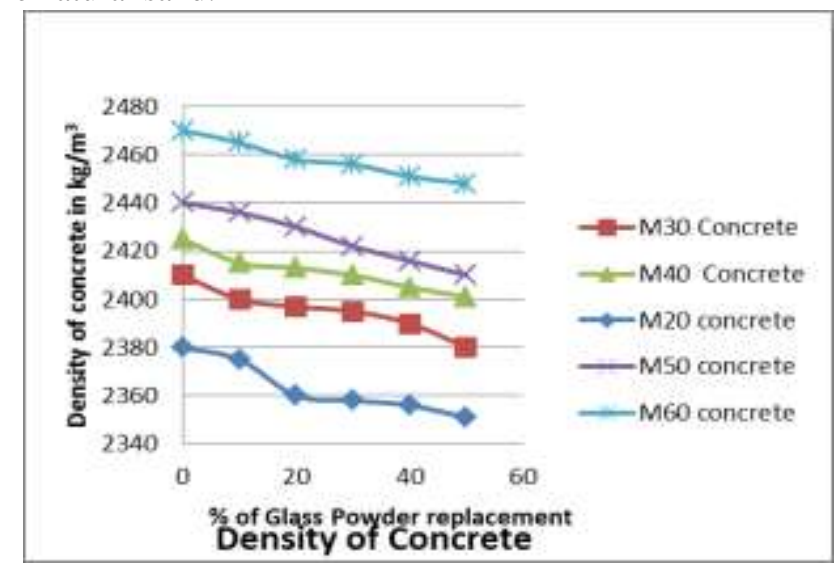

Figure 8 Bulk Density of M20 Concrete

\section{Mechanical strength:}

The compressive strength of concrete specimens of all the mixes designed was measured by compression test as per( IS: 516- 1959), the concrete cubes of size $150 \mathrm{~mm} \times 150 \mathrm{~mm} \times$ $150 \mathrm{~mm}$ were casted and tested after 28 days strength after conventional method of curing. Cylinder specimens of size $150 \mathrm{~mm}$ diameter and $300 \mathrm{~mm}$ height were used for cylinder compressive strength tests. For split tensile strength tests, cylinders of $150 \mathrm{~mm}$ diameter and $300 \mathrm{~mm}$ height specimens were casted and tested. Flexural strength test is conducted on concrete prisms of size $100 \mathrm{~mm} \times 100 \mathrm{~mm}$ x $500 \mathrm{~mm}$ size. The mean value of the strength of three specimens are reported for all the mechanical strength values of concrete.

Tests for Stress strain behaviour of M20 concrete mix with various \% of glass powder additions are done using cylinder specimens of $150 \mathrm{~mm}$ diameter and $300 \mathrm{~mm}$ height and

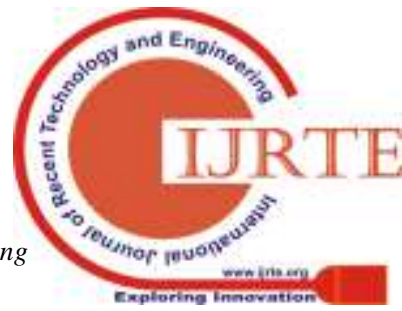


compressometer was used for strain measurements during uni-axial compression test.

\section{Test Results}

Concrete mixes of $20 \mathrm{MPa}, 30 \mathrm{MPa} 40 \mathrm{MPa}, 50 \mathrm{MPa}$ and $60 \mathrm{MPa}$ with glass powder partially substituting the natural river sand at $0 \%, 10 \%, 20 \%, 30 \%, 40 \%$ and $50 \%$ were produced and numerous tests were performed to study the workability properties and mechanical strength to obtain optimum \% of glass powder which gives better or comparable concrete to normal concrete. The recorded slump density of hardened concrete incorporated with glass powder decreases with the higher $\%$ of glass powder contents. The Test results of all the mechanical strengths are given in Table 2.8 through Table 2.22. and plotted in graphs Figure 7 to Figure 19 .
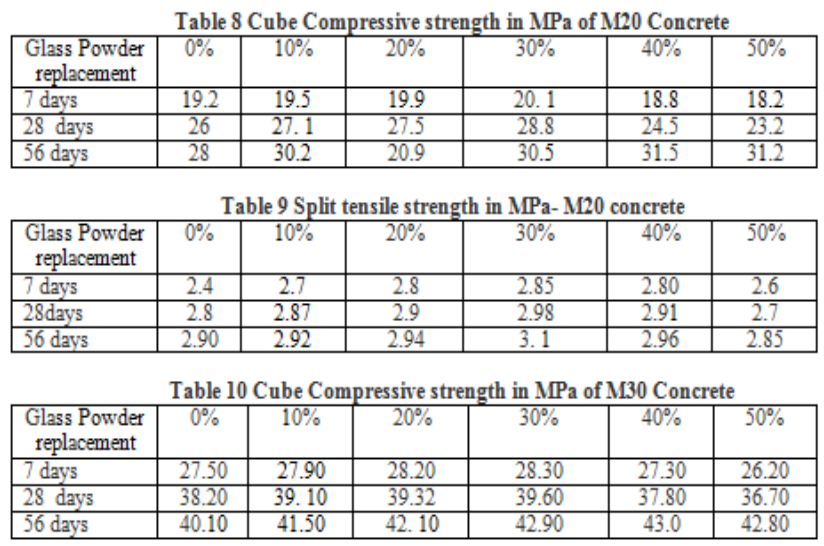

Table 11 Split tensile strength test in MPa - M30 concrete
\begin{tabular}{|l|c|c|c|c|c|c|}
\hline $\begin{array}{c}\text { Glass Powder } \\
\text { replacement }\end{array}$ & $0 \%$ & $10 \%$ & $20 \%$ & $30 \%$ & $40 \%$ & $50 \%$ \\
\hline 7 days & 3.2 & 3.4 & 3.71 & 3.82 & 3.66 & 3.22 \\
\hline 28 days & 3.92 & 3.96 & 3.98 & 4.03 & 3.80 & 3.65 \\
\hline 56 days & 4.1 & 4.15 & 4.22 & 4.26 & 4.02 & 3.82 \\
\hline
\end{tabular}

Table 12 Cube Compressive strength in MPaof M40 Concrete

Table $\mathbf{1 2}$ Cube Compressive strength in MPaof M40 Concrete
\begin{tabular}{|l|c|c|c|c|c|c|}
\hline $\begin{array}{c}\text { Glass Powder } \\
\text { replacement }\end{array}$ & $0 \%$ & $10 \%$ & $20 \%$ & $30 \%$ & $40 \%$ & $50 \%$ \\
\hline 7 days & 37.5 & 37.9 & 38.1 & 38.3 & 37.1 & 36.20 \\
\hline 28 days & 52.30 & 52.90 & 53.50 & 53.8 & 52.1 & 51.20 \\
\hline 56 days & 54.20 & 55.10 & 55.20 & 56.10 & 56.80 & 57.20 \\
\hline
\end{tabular}
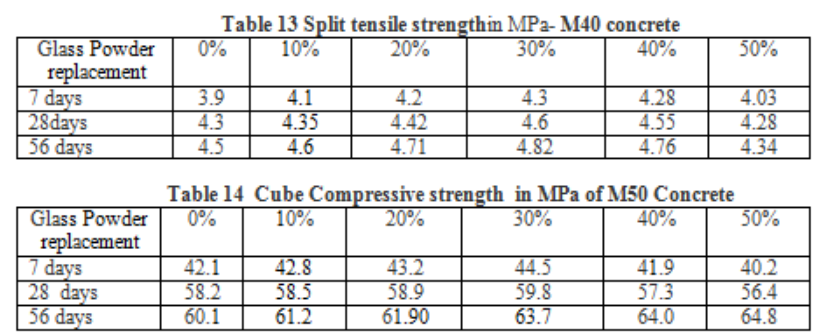

Table 15 Split tensile strength in MPa - M50 concrete
\begin{tabular}{|l|c|c|c|c|c|c|}
\hline $\begin{array}{l}\text { Glass Powder } \\
\text { replacement }\end{array}$ & $0 \%$ & $10 \%$ & $20 \%$ & $30 \%$ & $40 \%$ & $50 \%$ \\
\hline 7 days $(\mathrm{MPa})$ & 4.50 & 4.58 & 4.63 & 4.70 & 4.44 & 4.1 \\
\hline $\begin{array}{l}28 \text { days } \\
(\mathrm{MPa})\end{array}$ & 4.82 & 4.85 & 4.90 & 5.10 & 4.80 & 4.6 \\
\hline $\begin{array}{l}56 \text { days } \\
(\mathrm{MPa})\end{array}$ & 4.94 & 4.98 & 5.20 & 5.60 & 4.89 & 4.75 \\
\hline
\end{tabular}

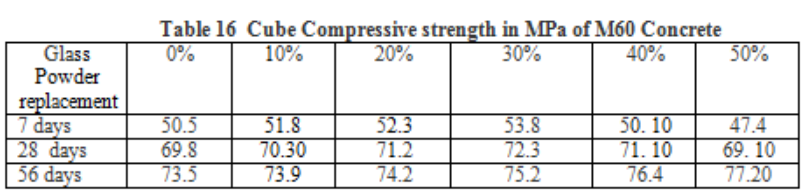
increased with the increase of glass powder content. The

Table 17 Split tensile strength in MPa- M60 concrete

\begin{tabular}{|l|c|c|c|c|c|c|}
\hline $\begin{array}{c}\text { Glass } \\
\text { Powder } \\
\text { replacement }\end{array}$ & $0 \%$ & $10 \%$ & $20 \%$ & $30 \%$ & $40 \%$ & $50 \%$ \\
\hline 7 days & 4.2 & 4.40 & 4.70 & 5.10 & 4.10 & 3.90 \\
\hline 28 days & 5.1 & 5.26 & 5.35 & 5.32 & 5.02 & 4.93 \\
\hline 56 days & 5.8 & 6.10 & 6.30 & 6.42 & 5.45 & 5.12 \\
\hline
\end{tabular}

Table 18 Cylinder compressive strength in MPa for various Mixes

\begin{tabular}{|l|l|l|l|l|l|}
\hline $\begin{array}{l}\text { Glass Powder } \\
\text { replacement \% }\end{array}$ & M20 & M30 & M40 & M50 & M60 \\
\hline 0 & 21.2 & 30.65 & 41.9 & 47.20 & 56.1 \\
\hline 10 & 22.1 & 31.52 & 42.5 & 47.80 & 56.5 \\
\hline 20 & 22.7 & 32.10 & 43.2 & 48.1 & 57.3 \\
\hline 30 & 23.9 & 32.70 & 43.8 & 49.20 & 58.2 \\
\hline 40 & 20.2 & 31.54 & 41.9 & 47.2 & 57.1 \\
\hline 50 & 19.86 & 30.11 & 41.2 & 46.3 & 55.9 \\
\hline
\end{tabular}

Table 19 Cube Compressive strength in $\mathrm{MPa}$ for various concrete mixes (28 days)

\begin{tabular}{|c|c|c|c|c|c|c|}
\hline $\begin{array}{c}\text { \% replacement of } \\
\text { glass powder }\end{array}$ & $0 \%$ & $10 \%$ & $20 \%$ & $30 \%$ & $40 \%$ & $50 \%$ \\
\hline M220 & 26 & 27.1 & 27.5 & 28.8 & 24.5 & 23.2 \\
\hline $\mathrm{M} 330$ & 38.20 & 39.10 & 39.32 & 39.60 & 37.80 & 36.70 \\
\hline $\mathrm{M} 40$ & 52.30 & 52.90 & 53.50 & 53.8 & 52.1 & 51.20 \\
\hline $\mathrm{M} 50$ & 58.2 & 58.5 & 58.9 & 59.8 & 57.3 & 56.4 \\
\hline $\mathrm{M} 600$ & 69.8 & 70.30 & 71.2 & 72.3 & 71.10 & 69.10 \\
\hline
\end{tabular}

Table 20 Modulus of elasticityin MPa for various \%o of Glass Powder
\begin{tabular}{|l|l|l|l|l|l|}
\hline $\begin{array}{l}\text { Glass } \\
\text { Powder } \\
\%\end{array}$ & M20 & M30 & M40 & M50 & M60 \\
\hline 0 & 24985 & 30910 & 33200 & 36200 & 38020 \\
\hline 10 & 25500 & 30920 & 33220 & 36300 & 38120 \\
\hline 20 & 25650 & 30930 & 33400 & 36400 & 38290 \\
\hline 30 & 26300 & 30970 & 33450 & 36450 & 38320 \\
\hline 40 & 26500 & 31300 & 34020 & 36600 & 38500 \\
\hline 50 & 27200 & 31400 & 34040 & 36700 & 38620 \\
\hline
\end{tabular}

Table 21 Cube compressive strength in $M \mathbb{P a}(28$ days)

Table 21 Cube compressive strength in MPa (28 days)
\begin{tabular}{|l|l|l|l|l|l|}
\hline $\begin{array}{l}\text { Glass } \\
\text { Powder } \\
\%\end{array}$ & M20 & M30 & M40 & M50 & M60 \\
\hline 0 & 26.0 & 38.20 & 52.30 & 58.20 & 69.8 \\
\hline 10 & 27.1 & 39.10 & 52.90 & 58.50 & 70.3 \\
\hline 20 & 27.5 & 39.32 & 53.50 & 58.90 & 71.2 \\
\hline 30 & 28.8 & 39.60 & 53.80 & 59.80 & 72.3 \\
\hline 40 & 24.5 & 37.80 & 52.10 & 57.30 & 71.10 \\
\hline 50 & 23.2 & 36.70 & 51.20 & 56.4 & 69.10 \\
\hline
\end{tabular}

Table 22 Cylinder compressive strength (in $\mathrm{MPa}$ ) for various concrete mixes

\begin{tabular}{|c|l|l|l|l|l|}
\hline \% of Glass powder & M20 & M30 & M40 & M50 & M60 \\
\hline 0 & 21.2 & 30.65 & 41.9 & 47.20 & 56.1 \\
\hline 10 & 22.1 & 31.52 & 42.5 & 47.80 & 56.5 \\
\hline 20 & 22.7 & 32.10 & 43.2 & 48.1 & 57.3 \\
\hline 30 & 23.9 & 32.70 & 43.8 & 49.20 & 58.2 \\
\hline 40 & 20.2 & 31.54 & 41.9 & 47.2 & 57.1 \\
\hline 50 & 19.86 & 30.11 & 41.2 & 46.3 & 55.9 \\
\hline
\end{tabular}

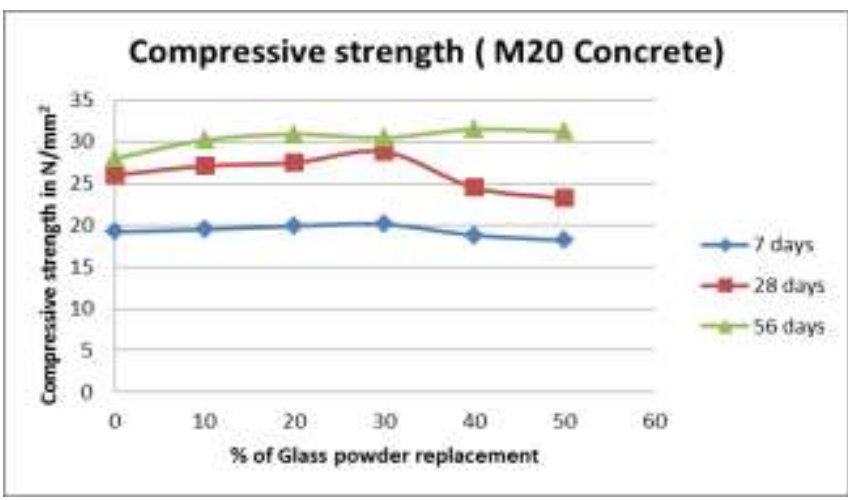

Figure 7 Compressive strength M20 concrete for various \% of glass powder

Published By:

Blue Eyes Intelligence Engineering 


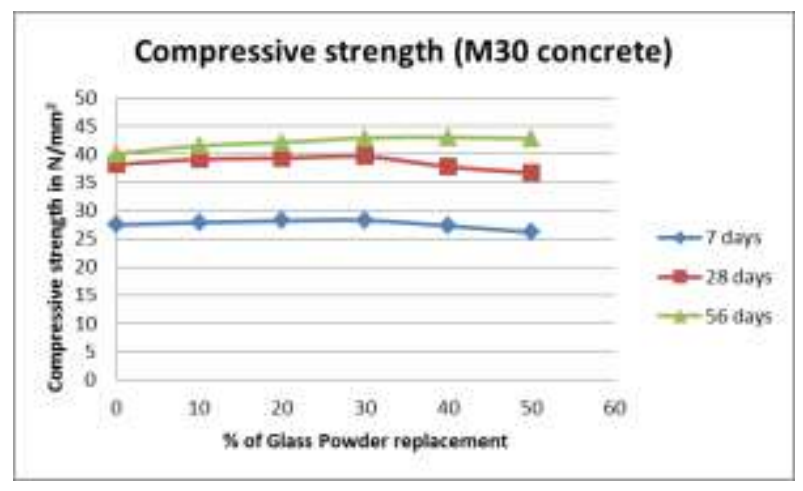

Figure 8 Compressive strength M30 concrete for various \% of glass powder

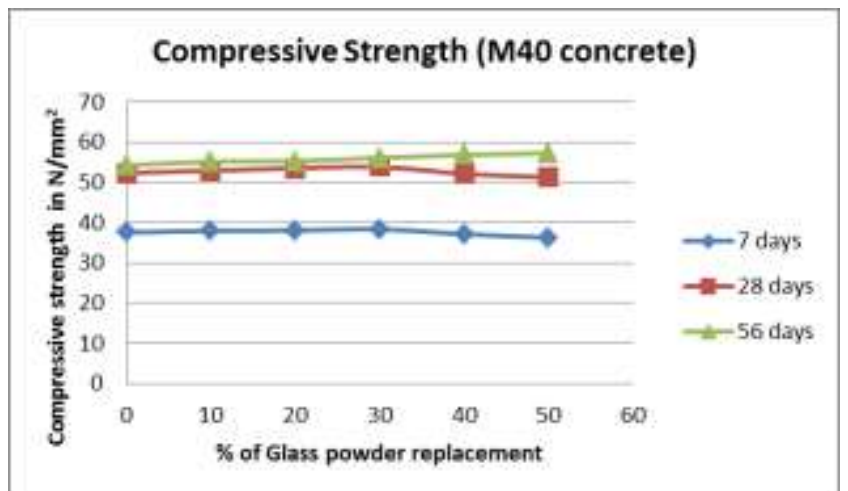

Figure 9 Compressive strength M40 concrete for various \% of glass powder

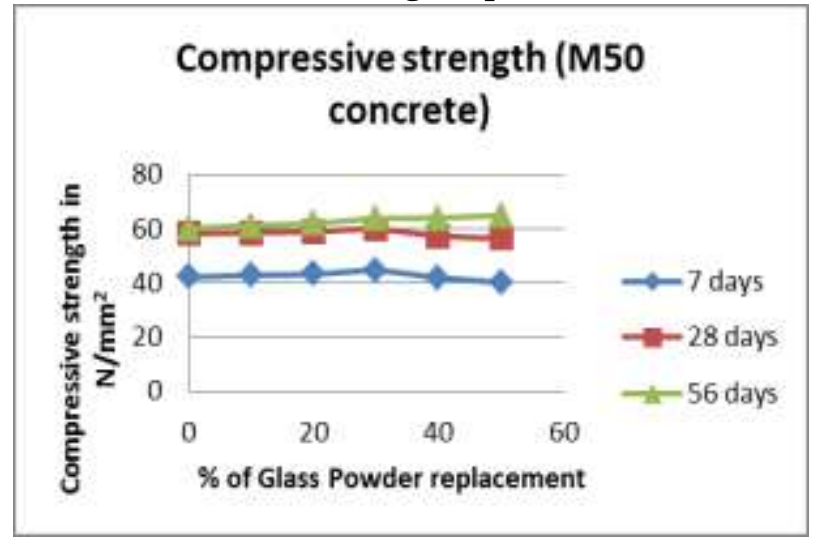

Figure 10 Compressive strength M50 concrete for various \% of glass powder

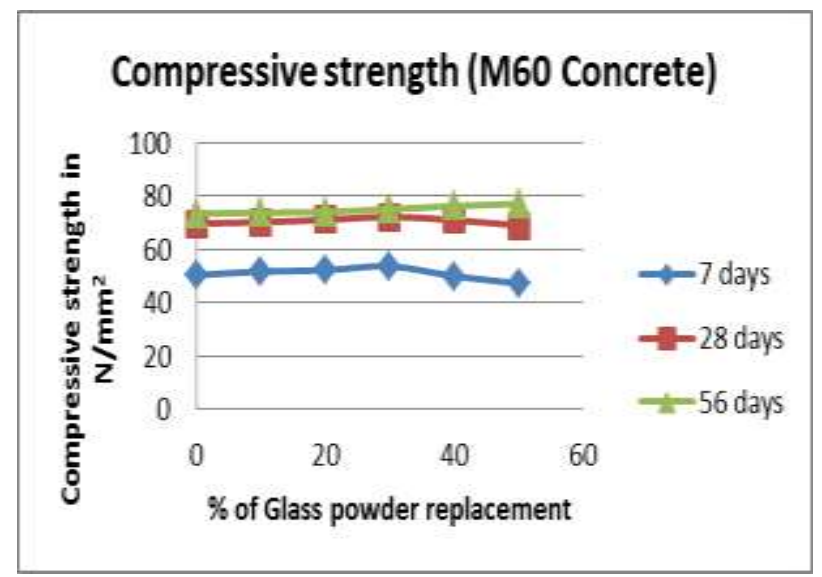

Figure 11 Compressive strength M60 concrete for various \% of glass powder

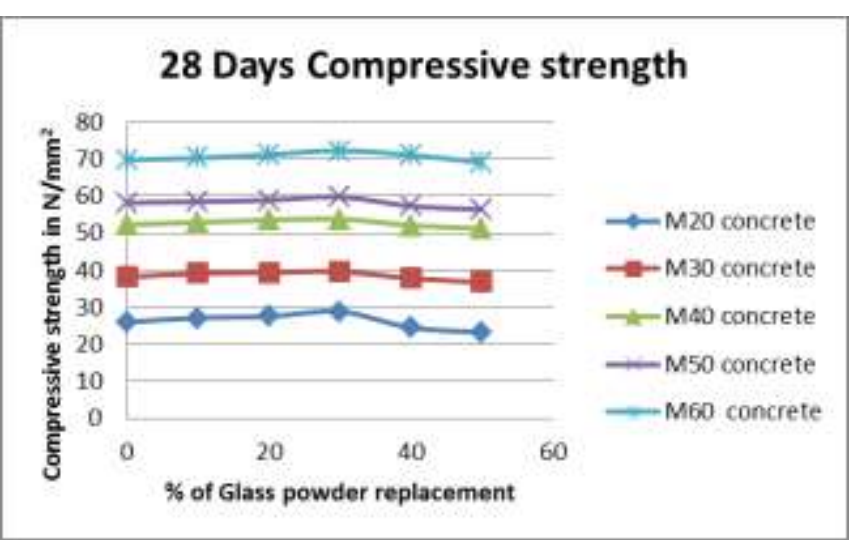

Figure 12 Compressive strength at 28 days for various grade of concrete

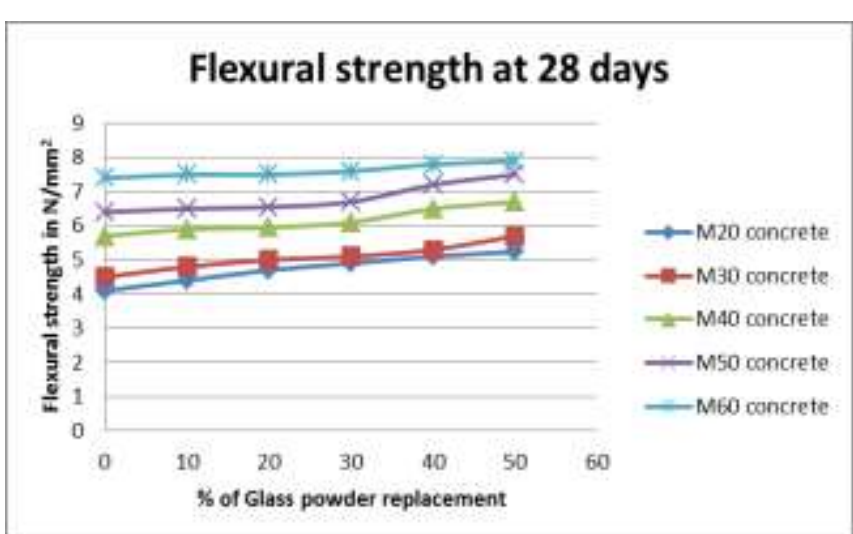

Figure 13 Flexural strength at 28 days for various grade of concrete

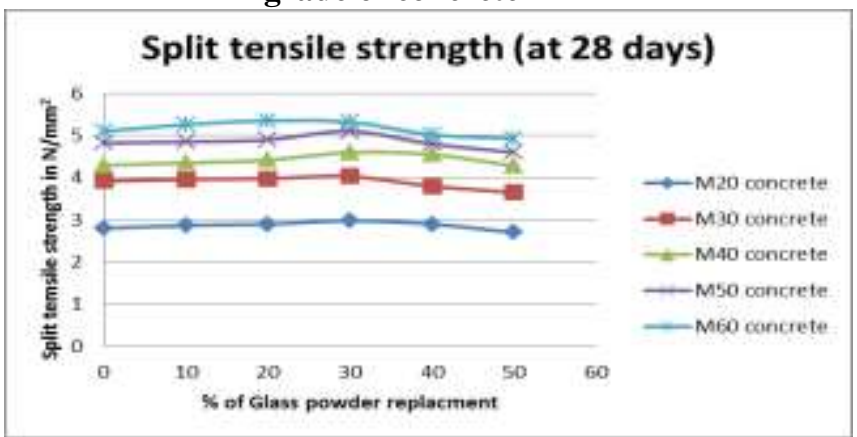

Figure 14Split tensile strength at 28 days for various grade of concrete

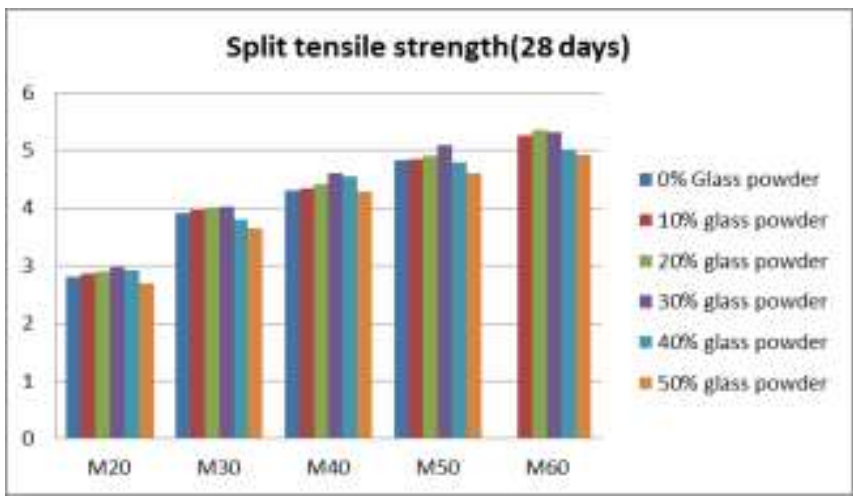

Figure 15Split tensile strength at 28 days for various $\%$ of glass powder and different concrete grades

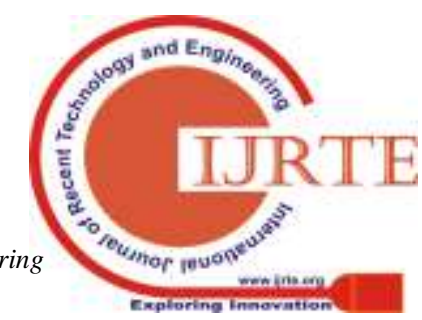




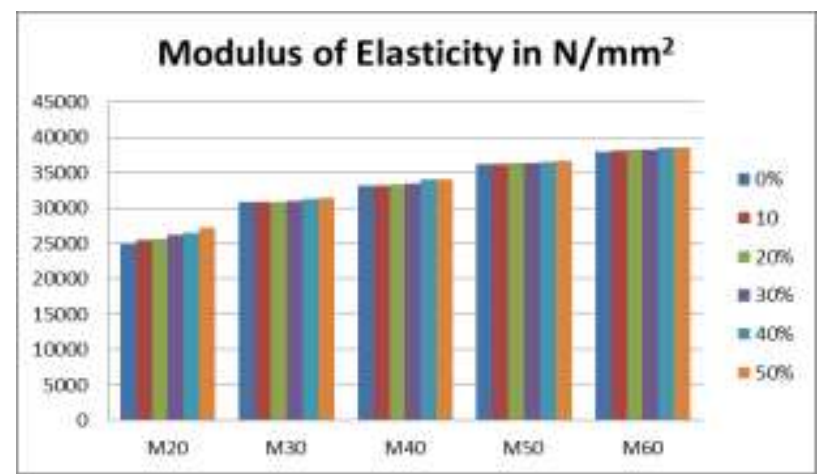

Figure 16 Modulus of elasticity of concrete with various \% of glass powder

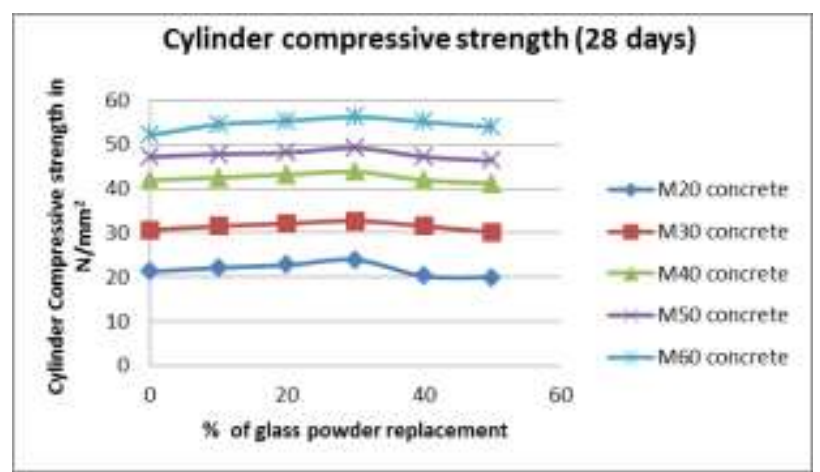

Figure 17 Cylinder compressive strength of concrete with various \% of glass powder

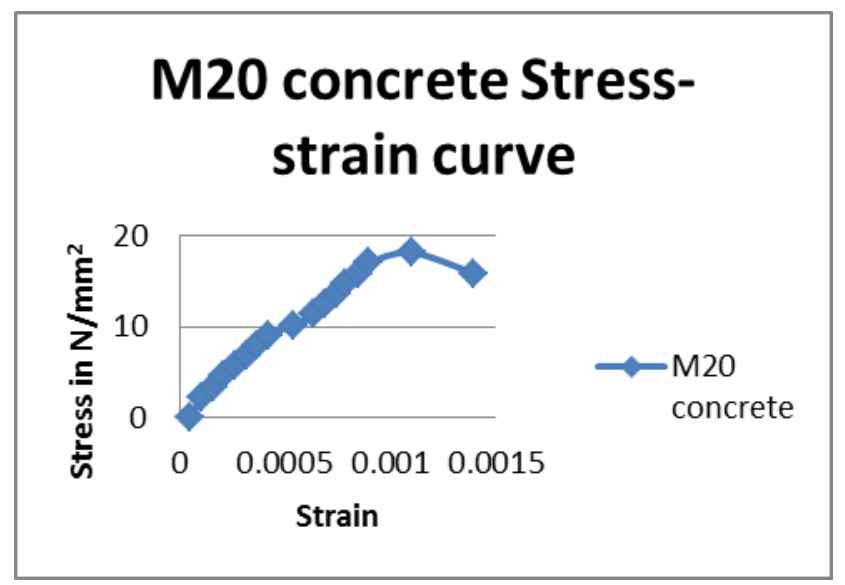

Figure 18 Stress Strain curve for M20 concrete with $30 \%$ glass powder replacement

\section{M40 concrete Stress strain curve}

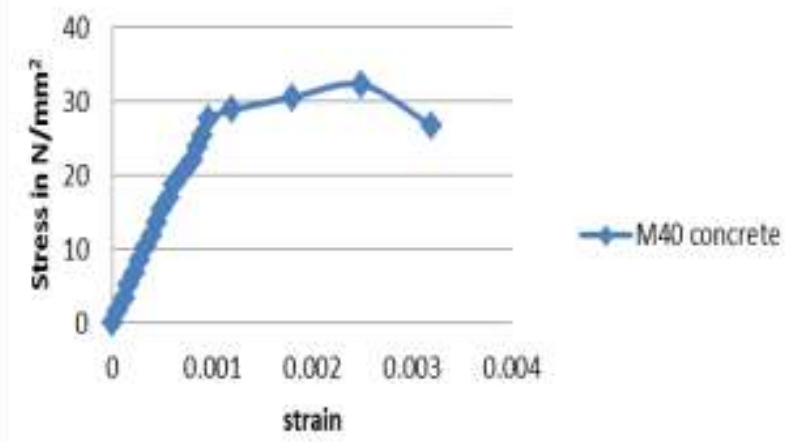

Figure 19 Stress Strain curve for M40 concrete with $30 \%$ glass powder replacement

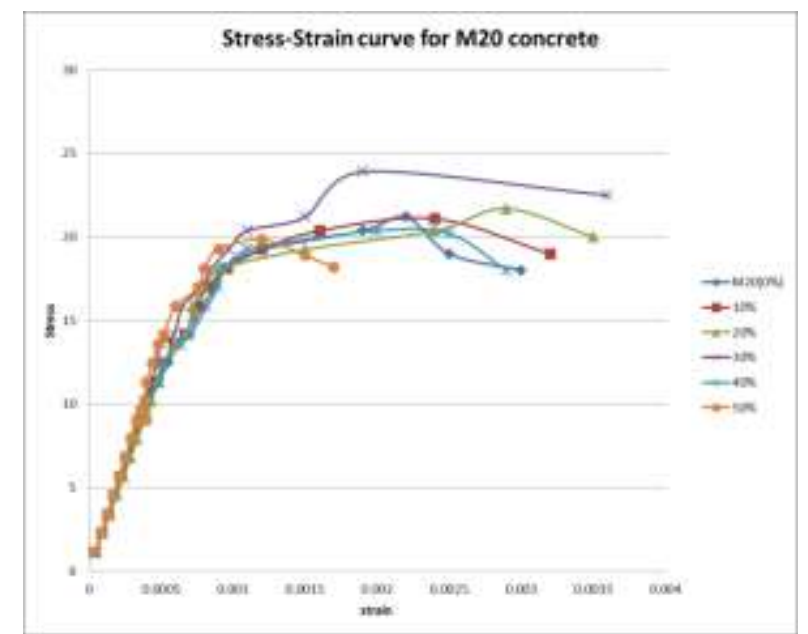

Figure 20 Stress Strain curve for M20 concrete with various \% glass powder replacement

Rapid Chloride Permeability Test (RCPT) Test

The RCPT tests were doneas per ASTM C1202 for the specimens of all the mixes M20,M30,M40,M50 and M60 with various percentage of glass powder $0 \%, 10 \%, 20 \%, 30 \%, 40 \%$ and $50 \%$ after 28 days curing. The cylindrical test specimens are of size $100 \mathrm{~mm}$ in diameter and $50 \mathrm{~mm}$ in thickness which had been conditioned according to the standard were placed in the cells and subjected to a $60-\mathrm{V}$ potential for $6-\mathrm{h}$. One of the cells was filled with $0.3 \mathrm{~N} \mathrm{NaOH}$ solution while the other filled with $3 \% \mathrm{NaCl}$ solution. The amount of electrical current passed through the specimen is measured and the total charge passed (in coulombs) is used as an indicator of the resistance of the concrete to chloride ion penetration. The RCPT test set up is shown in Figure 3.25. The total charge passed through the concrete specimens was calculated using the following formula in Eq. (1)

$$
Q=900\left(I_{o}+2 I_{30}+2 I_{60}+\ldots . . I_{360}\right)
$$

Where, $\mathrm{Q}=$ charge passed (coulombs),

Io $=$ current (amperes) immediately after voltage is applied and

It $=$ current (amperes) at $\mathrm{t}$ min after voltage is applied.

Rapid Chloride Permeability Test was conducted for the standard concrete specimens at 28 days to find the chloride permeability properties. The Chloride ion penetration properties of various mixes are indicated by the total amount of charge passing through the sample specimens (Table25,) It is observed that with increase in \% of Glass powder replacement, the chloride ion permeability of concrete mixes are reduced for all the grades of concrete mixes. With the addition of glass powder the chloride ion penetration of the concrete is found to be at the moderate level. With the addition of glass powder, the chloride permeability is reduced to maximum extent by $50 \%, 45 \%, 44 \%, 32 \%, 32 \%$ of normal concrete for M20, M30, M40, M50, M60 concrete with $50 \%$ glass powder replacements respectively. Therefore, concrete with glass powder replacements for sand exhibit low chloride permeability compared to the control concrete. 
Table 23RCPT Test Results ( at 28 days)

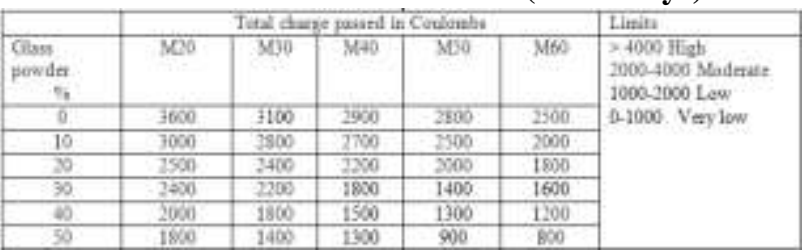

\section{Charge Passed in Coulombs}

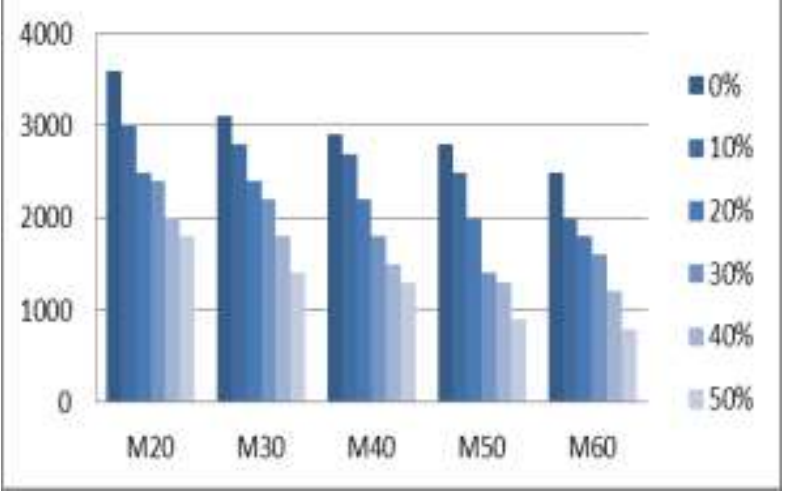

Figure 23Chloride Permeability Test Results

\section{CONCLUSIONS}

- The mix design for concrete with five various grades ( M20, M30, M40, M50, M60) was done. Extensive experimental study on strength and durability properties of these five grades of concrete with different $\%$ of $(0 \%, 10 \%$, $20 \%, 30 \%, 40 \%$ and $50 \%$ ) waste glass powder for fine aggregate replacement was carried out.

- The stress strain behaviour of all the above concrete mixes was investigated and reported in this section.

- According to the test results, it is observed that the slump value of fresh concrete increase gradually with $\%$ of glass powder upto $40 \%$ replacements.

- The compressive strength, flexural strength and split tensile strength gradually increase upto $30 \%$ addition of waste glass powder and for $40 \%$ and $50 \%$ replacements the strength values are comparable with that of the control specimens.

- The RCPT test results show that the chloride penetration rate is highly reduced with addition of glass powder and permeability properties of concrete is enhanced upto $50 \%$ replacement levels. Therefore $50 \%$ of glass powder can be used as the replacement material for fine aggregates without affecting the strength properties of the concrete.

\section{REFERENCES}

1. Ismail, ZZ \& Al-Hashmi, EA., "Recycling of waste glass as a partial replacement for fine aggregate in concrete", Waste Manag., vol. 29, 2009, pp. 655-659.

2. Limbachiya, M., "Bulk engineering and durability properties of washed glass sand concrete", Constr. Build. Mater.,vol. 23, 2009, pp. 1078-1083.

3. Balakrishnan, Nagaraj, Arunkumar Rajendran, and Karthigaikumar Palanivel. "Meticulous fuzzy convolution $\mathrm{C}$ means for optimized big data analytics: adaptation towards deep learning." International Journal of Machine Learning and Cybernetics (2019): 1-12.

4. Tuncan, M, Karasu, B \& Yalcin, M., "The suitability for using glass and fly ash in Portland cement concrete",
Proceedings of the International Offshore and Polar Engineering Conference, 2001, pp. 146-152.

5. Malik, M, Bashir, M, Ahmed, S, Tariq, $\mathrm{T}$ \& Chowdhary, U., "Study of concrete involving use of waste glass as partial replacement of fine aggregates", IOSR. J. Eng., vol. 3, no.7, 2013, pp.8-13.

6. Du, H, Tan, KH., "Concrete with recycled glass as fine aggregates", ACI Mater. J, 111-M05, 2014, pp. 47-58.

7. Park, SB, Lee, BC \& Kim, JH., "Studies on mechanical properties of concrete containing waste glass aggregate", Cem. Conc. Res., vol. 34, no. 12, 2004, pp. 2181-2189.

8. IS: 12269 (1989). Specification for 53 grade ordinary portland cement, Bureau of Indian Standards, New Delhi.

9. IS: 4031-Part 4 (1995). Method of physical testfor hydraulic cement, Bureau of Indian Standards, New Delhi.

10. IS: 383 (1987). Specification for coarse and fine aggregate from natural sources for concrete,8th Reprint October 1991, Bureau of Indian Standards, New Delhi. IS: 1199 . 1959

11. IS: 10262 (1982). Hand book of concrete mix design, Bureau of Indian Standards, New Delhi. 